\title{
Comparison of Epstein-Barr virus genotypes and clinicohistopathological features of nasopharyngeal carcinoma between Guilin, China and Fukuoka, Japan
}

\author{
YINGQIONG ZHOU $^{1,2}$, KAZUKI NABESHIMA ${ }^{1}$, KAORI KOGA ${ }^{1}$, MIKIKO AOKI ${ }^{1}$, \\ HIROYUKI HAYASHI $^{1}$, MAKOTO HAMASAKI ${ }^{1}$ and HIROSHI IWASAKI ${ }^{1}$ \\ ${ }^{1}$ Department of Pathology, Fukuoka University Hospital and School of Medicine, Fukuoka \\ University, 7-45-1 Nanakuma, Jonan-ku, Fukuoka 814-0180, Japan; ${ }^{2}$ Department of \\ Pathology, Guilin Medical College, Guangxi, Guilin 541001, P.R. China
}

Received January 9, 2008; Accepted February 27, 2008

\begin{abstract}
Epstein-Barr virus (EBV)-associated nasopharyngeal carcinoma (NPC) is endemic to Guilin, China, but not Fukuoka, Japan. To examine whether the NPC in these two cities are distinct in their association with EBV, we analyzed the histology and EBV genotypes in 163 NPC from Guilin, 52 NPC from Fukuoka and non-cancerous control nasopharyngeal tissues $(\mathrm{n}=22$ each) by in situ hybridization and PCR. The proportion of EBV-positive NPC from Guilin (95\%) was higher than that of Fukuoka $(55 \%, \mathrm{p}<0.001)$, and higher in NPC versus control tissues in Guilin (95 vs. 46\%) and Fukuoka (55 vs. $32 \%$ ). Histopathologically, non-keratinizing carcinoma and the undifferentiated subtype (NKC-U) were predominant in Guilin (84\%), while the proportion of keratinizing squamous cell carcinoma (KSCC, 38\%) was similar to NKC-U (42\%) in Fukuoka. EBV-positivity was higher in NKC-U than KSCC in the two cities. EBV genotype A was highly prevalent in Guilin and Fukuoka. However, the BamHI f variant was predominant in Guilin (79\%), whereas all the identified types were the F prototype in Fukuoka. The genetic structure and biological functions of the EBV strain associated with endemic NPC in Guilin were probably different from those of Fukuoka. The genetic differences between Guilin and Fukuoka may mirror the differences in histology and patient profiles.
\end{abstract}

\section{Introduction}

Nasopharyngeal carcinoma (NPC) is a common cancer in Southern China, especially in the Guangdong and Guangxi regions, where the incidence is $\sim 30-50 / 100,000$, but is rare in

Correspondence to: Dr Kazuki Nabeshima, Department of Pathology, Fukuoka University Hospital and School of Medicine, Fukuoka University, 7-45-1 Nanakuma, Jonan-ku, Fukuoka 814-0180, Japan

E-mail: kaznabes@fukuoka-u.ac.jp

Key words: nasopharyngeal carcinoma, Epstein-Barr virus, EpsteinBarr virus subtype
European and North American countries (incidence <1/ $100,000)(1)$, indicating a distinct geographical and racial distribution. The incidence of NPC is also low in Japan (2). The etiology of NPC is poorly understood but is probably multifactorial, including the interplay of genetic susceptibility, infection with Epstein-Barr virus (EBV) and environmental factors (dietary and non-dietary). It seems that genetic factors significantly increase the risk of NPC, but the almost constant association of EBV with NPC, irrespective of ethnic background, indicates a probable oncogenic role for $\mathrm{EBV}$ in the pathogenesis of NPC (1).

EBV can establish latent infection and is maintained in a life-long carrier state. Two methods have proven effective for localizing the EBV latent gene product in formalin-fixed tissues: 1) the immunohistochemical detection of the EBV latent membrane protein $(3,4)$ and 2$)$ detection of small nonpolyadenylated EBV-encoded RNAs (EBER) by non-isotopic in situ hybridization (5-9). EBV can be classified as types A (or 1) and B (or 2), and are distinguishable by their genetic polymorphism in the EBV nuclear antigen (EBNA)-2, -3, -4 and -6 with distinct DNA sequences and protein antigenic variations (10-12). The different EBV strains may affect the transformation ability or cytotoxic immune responses leading to different human diseases. Genotype A is more efficient than B in immortalizing B-cell growth, while genotype B has a stronger lytic ability (13-16). Although EBV is ubiquitous in health populations throughout the world, the incidence of different EBV genotype-associated tumors shows considerable geographic variation. The type A strain is predominant in tumor tissues from Europe, Japan and North America, whereas genotype B has been found mainly in Central Africa and New Guinea $(15,17)$. Type A EBV is also prevalent in health-seropositive individuals in Southern China and the Hong Kong area $(18,19)$. An analysis of genotypic differences using restriction fragment length polymorphism (RFLP) has shown more than two EBV genotypes $(20,21)$. Previous studies have identified a genetic variant of EBV with an extra Bam HI site in the BamHI F region (f variant). The f variant appears to be much more frequent in the NPC patients $(86 \%)$ of Southern China than healthy Chinese individuals (8\%), 
Table I. The primers used.

\begin{tabular}{|c|c|c|c|c|}
\hline Genome region & Primers & Primer sequences 5'-3' & PCR product $(\mathrm{bp})$ & References \\
\hline \multirow[t]{2}{*}{ ß-globin gene } & $\mathrm{PC} 03$ & ACA CAA CTG TGT TCA CTA GC & 123 & Borisch et al (1993) (6) \\
\hline & PC04 & CAA CTT CAT CCA CGT TCA CC & & \\
\hline \multirow[t]{2}{*}{ EBNA-2A } & $2 \mathrm{AB}-\mathrm{s}$ & CTA TCT TGC GTT ACA TGG GGG ACA & 177 & Borisch et al (1992) (26) \\
\hline & $2 \mathrm{~A}$-as & GGG AGT GGT GGG GGC ACC CCC & & \\
\hline \multirow[t]{2}{*}{ EBNA-2B } & $2 \mathrm{AB}-\mathrm{s}$ & CTA TCT TGC GTT ACA TGG GGG ACA & 177 & Borisch et al (1992) (26) \\
\hline & 2B-as & TGG GGC GGT GCG GGT GCCCCA & & \\
\hline \multirow[t]{2}{*}{ Bam HI-F } & $\mathrm{F} 1$ & TCC CAC CTG TTA CCA CAT TC & 198 & Henry et al (2001) (27) \\
\hline & $\mathrm{F} 2$ & GGC AAT GGG ACG TCT TGT AA & & \\
\hline
\end{tabular}

suggesting that the f variant may be tumor-associated (20, 22-24).

In view of the above information, the present study was designed to delineate differences in EBV genotypes involved in NPC in the two neighboring countries of China and Japan, using NPC biopsy specimens from Guilin Medical College Hospital, China and Fukuoka University Hospital, Japan. Based on these differences, we then determined the relationship between the EBV genotype and histopathological features of NPC.

\section{Materials and methods}

Clinical samples. One hundred and sixty-three and 52 NPC biopsy specimens were collected from case files from the Department of Pathology, Guilin Medical College in China and the Department of Pathology, Fukuoka University Hospital in Japan, respectively, during the period 1980-2006. The tissue samples from Guilin were from 125 males and 38 females, ranging in age from 16 to 78 (median 44.5) years, while those from Fukuoka were from 41 males and 11 females, ranging in age from 32 to 92 (median 66.5) years. The specimens were fixed routinely in $10 \%$ formalin and processed into paraffin blocks for histopathological examination. Tissue sections were cut $4 \mu \mathrm{m}$ thick and stained with hematoxylin and eosin (H\&E). Histopathologically, NPC was classified into keratinizing squamous cell carcinoma (KSCC), non-keratinizing carcinoma-differentiated subtype (NKC-D), undifferentiated subtype (NKC-U) and basaloid squamous cell carcinoma (BSCC), based on the WHO classification of NPC (25). Nasopharyngeal tissues from 22 Chinese and 22 Japanese non-neoplastic cases were used as controls.

In situ hybridization for latent EBV infection. In situ hybridization for EBER was performed to confirm the presence of EBV in 217 NPC specimens. Sections $(4 \mu \mathrm{m})$ from paraffinembedded blocks were deparaffinized, re-hydrated and predigested with proteinase $\mathrm{K}$. The hybridization solution containing fluorescein isothiocyanate (FITC)-labeled EBV oligonucleotide probe (EBER PNA probe, Dako, Glostrup, Denmark) was applied for $90 \mathrm{~min}$ at $55^{\circ} \mathrm{C}$. A Dako ISH detection kit (code no. S2450) including rabbit $\mathrm{F}\left(\mathrm{ab}^{\prime}\right) 2$ antiFITC antibody, Envision reagent and 3,3'-diaminobenzidine (Sigma Chemical Co., St. Louis, MO) were used to visualize the hybridization products. The brown signals appearing within the nucleus were recognized as EBER-positive.

Sample DNA preparation. DNA was successfully extracted from the paraffin blocks of 156 Chinese and 29 Japanese EBER-positive NPC cases, using the method previously described (8). Briefly, 3-4 $10 \mu \mathrm{m}$-thick tissue sections from each case were placed in a sterile 1.5 - $\mathrm{ml}$ tube, deparaffinized and digested at $55^{\circ} \mathrm{C}$ for $20 \mathrm{~h}$ with $200 \mu \mathrm{g} / \mathrm{ml}$ proteinase $\mathrm{K}$ (Wako, Osaka, Japan) in $200 \mu 1$ of $1 \mathrm{X}$ polymerase chain reaction (PCR) buffer (Roche, Mannheim, Germany). Digestion was terminated by inactivating proteinase $\mathrm{K}$ at $96^{\circ} \mathrm{C}$ for $10 \mathrm{~min}$. Cell debris were colleted by centrifugation at $10,000 \mathrm{rpm}$ for $5 \mathrm{~min}$. The supernatant was transferred into a new tube and used directly for PCR.

Analysis of the EBNA-2 subtype. The successful DNA extraction for PCR from paraffin sections was confirmed in each case using primer pairs designed for the $\beta$-globin gene (PC03 and PC04) (Table I) (6). Cases with positive B-globin PCR products were analyzed to detect EBV subtypes. The identification of the EBV genotypes A and B was carried out by determining the 3 ' sequence divergence of the EBNA-2 gene by the HotStar PCR method as previously described (8), with some modifications. One common sense primer and two different anti-sense primers were used for amplification of the 177-bp EBNA-2A and -2B fragments (Table I) (26). Amplification was performed with $5 \mu \mathrm{l}$ of DNA extracts $(10 \mathrm{ng} / \mu \mathrm{l})$ from tissue samples, in a $50 \mu 1$ reaction mixture containing $3 \mathrm{mM} \mathrm{MgCl}_{2}, 0.2 \mathrm{mM}$ dNPTs mix (Invitrogen, Carlsbad, CA), $0.5 \mu \mathrm{M}$ of each primer, 2.5 units of HotStarTaq DNA polymerase (Qiagen, Hilden, Germany) and standard PCR buffer (Qiagen). Amplification was performed first with a cycle of $95^{\circ} \mathrm{C}$ for $15 \mathrm{~min}$ to activate the HotStarTaq DNA polymerase, then continued with 40 cycles of denaturation at $94^{\circ} \mathrm{C}$ for $1 \mathrm{~min}$, annealing at $55^{\circ} \mathrm{C}$ for $1 \mathrm{~min}$ and extension at $72^{\circ} \mathrm{C}$ for $1 \mathrm{~min}$, with the last extension at $72^{\circ} \mathrm{C}$ for $5 \mathrm{~min}$. Non-template control, consisting of master mix only, in a similar volume as the reaction mixture was included in each run of the PCR (GeneAmp ${ }^{\circledR}$ PCR system 9700, Applied Biosystems, Foster City, CA). PCR products were analyzed by electrophoresis in a $2 \%$ agarose gel. After completion of electrophoresis, the gels were photographed under the UV light transilluminator. Lymphoma with EBNA-2A subtype was 
Table II. Summary of NPC cases from Guilin and Fukuoka.

\begin{tabular}{|c|c|c|c|}
\hline & Guilin $(n=163)$ & Fukuoka $(\mathrm{n}=52)$ & P-value \\
\hline Ages (years), range (median) & $16-78(44.5)$ & $32-92(66.5)$ & \\
\hline Gender $(\mathrm{M} / \mathrm{F})$ & 3.3:1 & $3.5: 1$ & \\
\hline \multicolumn{4}{|l|}{ Histological type } \\
\hline Keratinizing squamous cell carcinoma & $11(6.7 \%)$ & $21(40.4 \%)$ & $<0.0001$ \\
\hline Non-keratinizing carcinoma-differentiated subtype & $15(9.2 \%)$ & $10(19.2 \%)$ & NS \\
\hline Non-keratinizing carcinoma-undifferentiated subtype & $137(84.0 \%)$ & $21(40.4 \%)$ & $<0.01$ \\
\hline
\end{tabular}

NS, not significant.

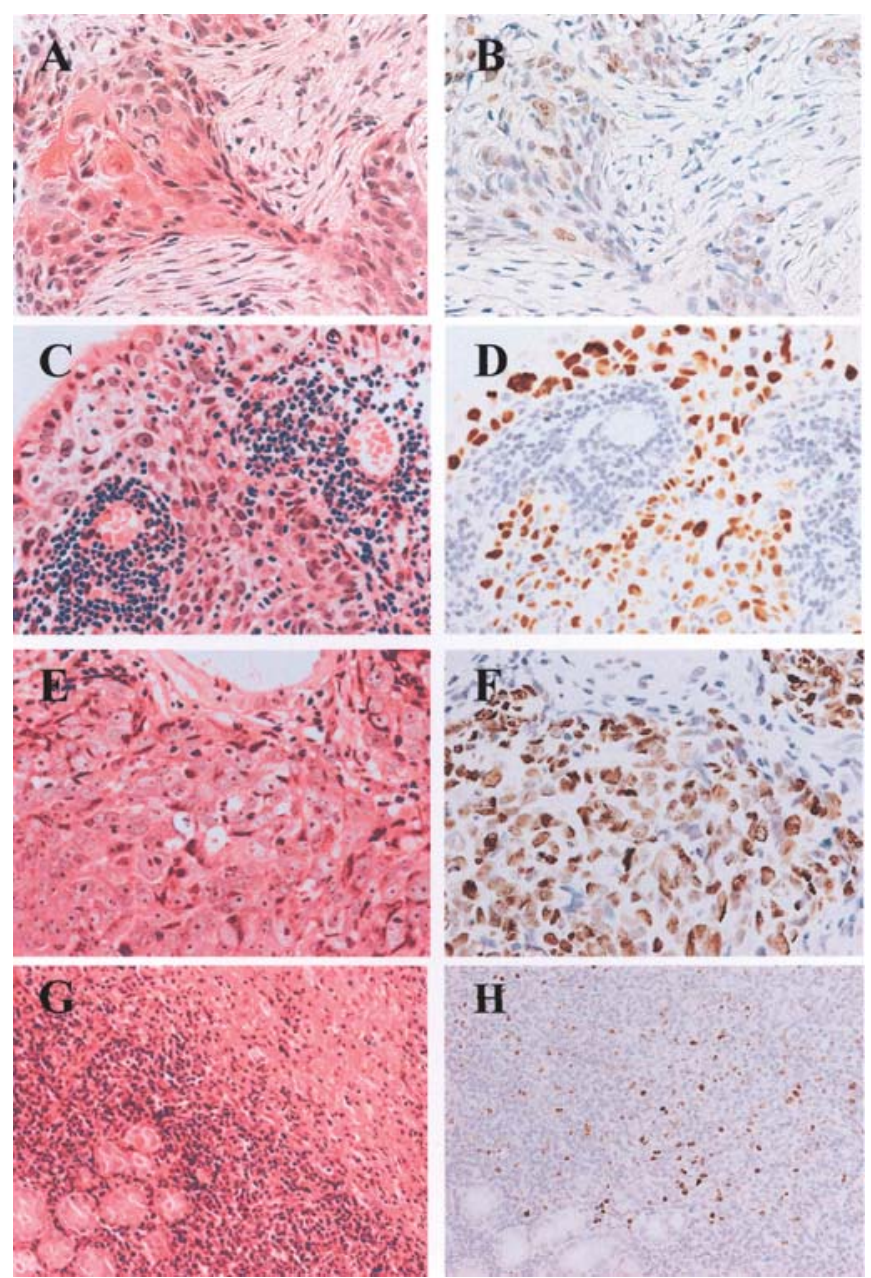

Figure 1. EBER in situ hybridization. EBER-positive carcinoma cells in (A and $\mathrm{B})$ keratinizing squamous cell carcinoma, (C and D) non-keratinizing carcinoma-differentiated type and $(\mathrm{E}$ and $\mathrm{F})$ non-keratinizing carcinomaundifferentiated type. ( $\mathrm{G}$ and $\mathrm{H}$ ) Non-neoplastic nasopharyngeal tissue containing EBER-positive lymphocytes (H\&E staining: A, C, E and G and EBER in situ hybridization: $\mathrm{B}, \mathrm{D}, \mathrm{F}$ and $\mathrm{H})$.

used as a positive control. In addition, PCR products from several representative NPC cases with the EBNA-2A or-2B subtype were subjected to sequence analysis as described below. Once the sequence of each subtype was confirmed, the cases were used as controls.
BamHI $F$ and $f$ variant analysis. The analysis of the EBV geno-types $\mathrm{F}$ and $\mathrm{f}$ was based on the presence of an extra restriction enzyme site at the BamHI-F fragment region of the EBV genome. PCR was performed using primers designed from the BamHI-F region (BamHI-F1 and -F2, Table I) (27). PCR was performed as described above $(8,21)$. After the PCR, $10 \mu 1$ PCR products were digested with $0.5 \mu 1$ of $50 \mathrm{U} / \mu 1$ Bam HI restriction enzyme (Promega, Madison, WI) at $37^{\circ} \mathrm{C}$ for $3 \mathrm{~h}$. The products were analyzed for the extra BamHI-F site by electrophoresis using a $3 \%$ agarose gel stained with ethidium bromide. The PCR product size of 198 bp was considered as genotype F, whereas the presence of the restriction site, which resulted in two bands of 127 and $71 \mathrm{bp}$, indicated genotype $\mathrm{f}$.

Sequence analysis of EBNA-2 DNA and BamHI $F$ and $f$ variants. To confirm the DNA sequences of EBNA-2A and $-2 \mathrm{~B}$ subtypes and Bam $\mathrm{HI} \mathrm{F}$ and $\mathrm{f}$ variants, the PCR products from representative NPC cases with each subtype/variant were purified using a QiAquick PCR purification kit (Qiagen). Direct sequencing of PCR products was performed using Applied Biosystems 3730 DNA analyzer (Applied Biosystems).

Statistical analysis. Statistical analysis was performed using the Chi-square test. A value of $\mathrm{P}<0.05$ was considered statistically significant.

\section{Results}

NPC cases. Table II provides a summary of NPC patients from Guilin, China and Fukuoka, Japan. The Japanese NPC patients were 22 years older than the Chinese. Males were predominant in the two groups. As for the histopathological types, NKC-U was much more frequent in Guilin (84.2\%) than in Fukuoka $(41.5 \%)$, but KSCC was much less frequent in Guilin $(6.7 \%)$ than in Fukuoka (43.4\%). No marked difference in NKC-D between the two districts existed.

EBER in NPC specimens detected by in situ hybridization. Table III summarizes the results of EBER in situ hybridization in association with the clinicopathological features of Guilin-Chinese and Fukuoka-Japanese NPC cases. EBERpositive signals were detected in the carcinoma cell nuclei of all histological types (Fig. 1). However, NKC-U (97.1\% in Guilin and $76.2 \%$ in Fukuoka) showed higher positive rates 
Table III. Summary of clinicopathological features and results of EBER in situ hybridization in Guilin, Chinese and Fukuoka, Japanese NPC cases.

\begin{tabular}{|c|c|c|c|c|c|c|c|c|}
\hline & \multirow[b]{2}{*}{ Cases } & \multicolumn{2}{|c|}{ EBER (Guilin) } & \multirow[b]{2}{*}{ P-value } & \multirow[b]{2}{*}{ Cases } & \multicolumn{2}{|c|}{ EBER (Fukuoka) } & \multirow[b]{2}{*}{ P-value } \\
\hline & & + & - & & & + & - & \\
\hline NPC & 163 & $155(95.1)$ & $8(4.9)$ & & 52 & $29(55.8)$ & $23(44.2)$ & \\
\hline \multicolumn{9}{|l|}{ Gender } \\
\hline Male & 125 & $119(95.2)$ & $6(4.8)$ & NS & 41 & $22(53.7)$ & $19(46.3)$ & NS \\
\hline Female & 38 & $36(94.7)$ & $2(5.3)$ & & 11 & 7 (63.6) & $4(36.4)$ & \\
\hline \multicolumn{9}{|c|}{ Age (years) } \\
\hline$<50$ & 109 & $103(94.5)$ & $6(5.5)$ & NS & 9 & $5(55.6)$ & $4(44.4)$ & NS \\
\hline $50-70$ & 54 & $52(96.3)$ & $2(3.7)$ & & 23 & $16(69.6)$ & $7(30.4)$ & \\
\hline$\geq 70$ & 1 & $1(100)$ & $0(0)$ & & 20 & $8(40.0)$ & $12(60.0)$ & \\
\hline \multicolumn{9}{|c|}{ WHO type } \\
\hline KSCC & 11 & $8(72.7)$ & $3(27.3)$ & NS & 21 & $10(47.6)$ & $11(52.4)$ & NS \\
\hline NKC-D & 15 & $15(100)$ & $0(0)$ & & 10 & $3(30.0)$ & $7(70.0)$ & \\
\hline NKC-U & 137 & $132(97.1)$ & $5(3.6)$ & $<0.05$ & 21 & $16(76.2)$ & $5(23.8)$ & $<0.05$ \\
\hline \multicolumn{9}{|c|}{ Neck mass } \\
\hline Yes & 62 & $58(93.5)$ & $4(6.5)$ & & 14 & $7(50.0)$ & $7(50.0)$ & \\
\hline No & 101 & $97(96.0)$ & $4(4.0)$ & NS & 38 & $22(57.9)$ & $16(42.1)$ & NS \\
\hline
\end{tabular}

KSCC, keratinizing squamous cell carcinoma; NKC, non-keratinizing carcinoma; -D, differentiated subtype; -U, undifferentiated subtype and NS, not significant.

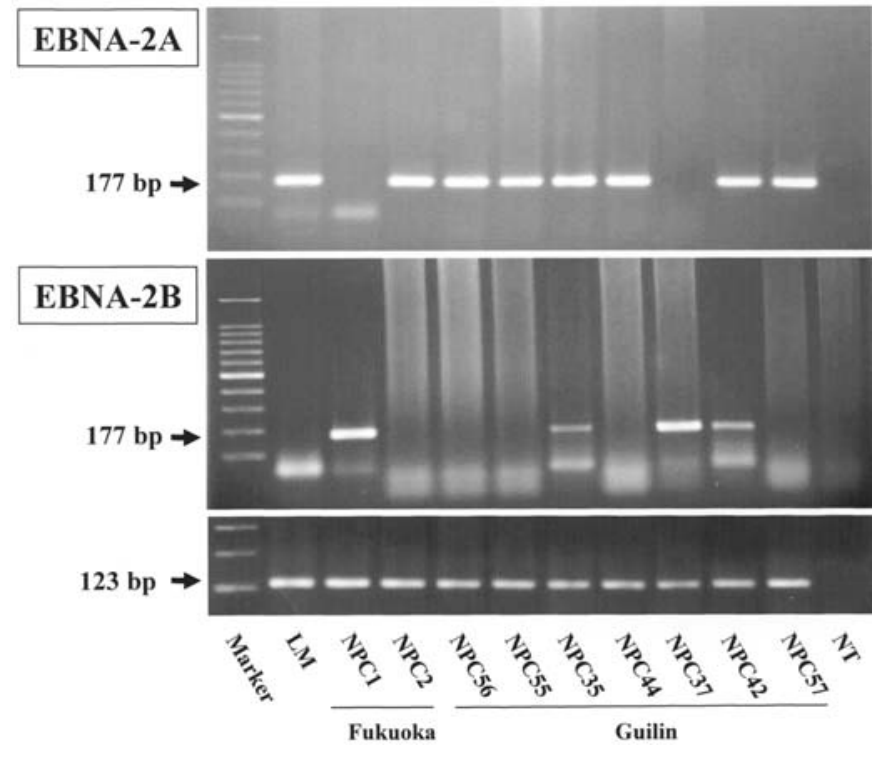

Figure 2. PCR typing of EBV genomes associated with NPC in two representative cases from Fukuoka and seven representative cases from Guilin. DNA samples prepared from NPC specimens were subjected to PCR amplification using EBV type-2 consensus primers. DNA from lymphoma with EBV (type 2A) was used as a control. All NPC cases show presence of the type $2 \mathrm{~A}$ product (177 bp), except for NPC1 and NPC37 cases (EBNA-2A). Four cases (NPC1, NPC35, NPC37 and NPC42) show the type $2 \mathrm{~B}$ product (177 bp), while all the other cases are negative. The human ß-globin gene provided amplification products of $123 \mathrm{bp}$. Marker, $100 \mathrm{bp}$ DNA ladder; LM, lymphoma; NPC, nasopharyngeal carcinoma (numbers indicate case numbers) and NT, non-template control. compared with KSCC (72.7\% in Guilin and $47.6 \%$ in Fukuoka) in the Chinese and Japanese cases (Table III). The positive rate in NKC-D was much higher in Guilin (100\%) than Fukuoka (14.3\%). Moreover, the positive rates were higher in the Chinese cases in all histological types. Lymphocytes in non-neoplastic nasopharyngeal tissue also showed EBERpositive signals in the two groups (Fig. 1G-H), and these positive rates in non-neoplastic tissues were not significantly different between Chinese and Japanese cases [10/22 (45.5\%) in Guilin vs. 7/22 (31.8\%) in Fukuoka].

EBV EBNA-2 subtype analysis. A subsequent genotypic analysis of EBV was carried out in 184 EBV-positive NPC specimens. Twenty-six and 135 cases from Fukuoka and Guilin, respectively, showed the successful amplification of $\beta$-globin by PCR. The other cases that did not show any $\beta$ globin bands ( 3 and 20 cases from Fukuoka and Guilin, respectively) were judged to have poorly preserved DNA and were excluded from further analysis. Positive EBNA-2 products were found by PCR in 12 out of 26 cases (46.2\%) and 45 out of 135 cases (33.3\%) from Fukuoka and Guilin, respectively (Fig. 2 and Tables IV and V). Seven of the positive cases from Guilin showed evidence of dual infection by types A and B of EBV ( 5 NKC-U, 1 NKC-U and 1 KSCC cases). Two NPC biopsies contained EBV DNA of type B, one from Guilin and the other from Fukuoka (in both NKC-U cases), whereas all the other amplifiable cases were infected with EBV type A virus (28 NKC-U, 6 NKC-D and 3 KSCC 
Table IV. Summary of clinical and histopathological features, results of EBER in situ hybridization and EBV genetic subtypes in Fukuoka, Japanese NPC cases.

\begin{tabular}{|c|c|c|c|c|c|c|}
\hline Case & Age (years) & Gender & Histology & EBER & EBNA-2 subtype & BamHI F/f \\
\hline 1 & 76 & Male & NKC-U & + & B & $\mathrm{F}$ \\
\hline 2 & 76 & Male & KSCC & + & A & $\mathrm{F}$ \\
\hline 3 & 57 & Female & KSCC & + & A & ND \\
\hline 4 & 61 & Male & NKC-U & + & A & ND \\
\hline 5 & 50 & Female & NKC-U & + & A & ND \\
\hline 6 & 64 & Male & KSCC & + & A & ND \\
\hline 7 & 62 & Male & KSCC & + & A & $\mathrm{F}$ \\
\hline 8 & 52 & Male & KSCC & + & A & ND \\
\hline 9 & 82 & Female & KSCC & + & A & ND \\
\hline 10 & 74 & Male & NKC-U & + & A & ND \\
\hline 11 & 60 & Female & NKC-U & + & A & ND \\
\hline 12 & 68 & Female & KSCC & + & A & $\mathrm{F}$ \\
\hline
\end{tabular}

KSCC, keratinizing squamous cell carcinoma; NKC, non-keratinizing carcinoma; -D, differentiated subtype; -U, undifferentiated subtype and $\mathrm{ND}$, not detected.

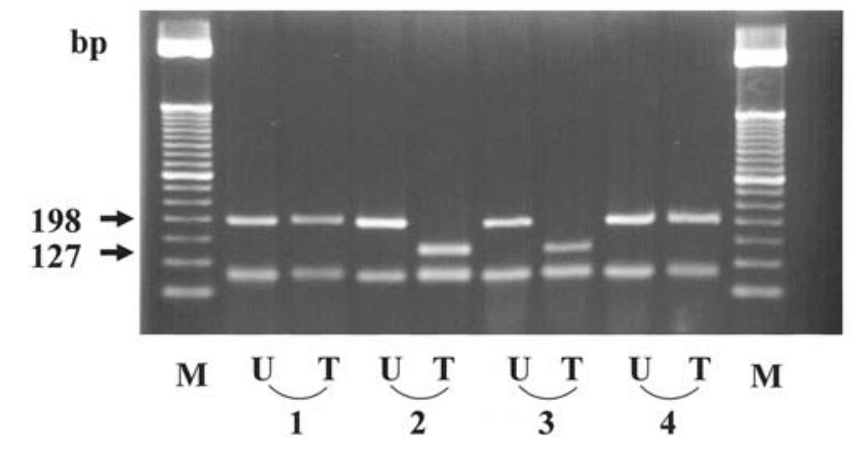

Figure 3. Differentiation of EBV genotypes $\mathrm{F}$ and $\mathrm{f}$ after restriction fragment length polymorphism with restriction endonuclease BamHI in four representative cases. Cases 1 (Guilin, no. 56) and 4 (Guilin, no. 46): genotype $\mathrm{F}$ in the tumor biopsies of patients with NPC. Cases 2 (Guilin, no. 57) and 3 (Fukuoka, no. 1): genotype $\mathrm{f}$ in the tumor biopsies of patients with NPC. U, untreated with BamHI; T, treated with BamHI and M, 50 pb DNA ladder.

from Guilin and 7 KSCC and 4 NKC-U from Fukuoka) (Fig. 2 and Tables IV and V).

Analysis of BamHI $F$ and $f$ variants. Further attempts to identify the variability in viral genotypes between Chinese and Japanese NPC cases were based on polymorphism in the BamHI F region of EBV DNA. The PCR amplified product of the prototype BamHI F fragment is 198 bp in size. Cleavage with the BamHI restriction enzyme yields two fragments of 127 and $71 \mathrm{bp}$ for the f variant. The results of the BamHI F analysis are shown in Fig. 3 and Tables IV and V. Amplification of the BamHI F region was successful in four Japanese (4/26) and 24 Chinese (24/135) NPC cases. The Japanese NPC cases showed an EBV B95.8-like wild-type F configuration (27) (one case infected with EBV type B and three cases infected with EBV type A). Five Chinese NPC cases (5/24, $21 \%$ ) showed a type F configuration (one case infected with
EBV types A and B and four cases infected with EBV type A) and $f$ variant was detected in 19 other Chinese cases (19/24, $79 \%$; four cases infected with EBV types A and B and 15 cases infected with EBV type A). Histological types included 3 NKC-U and 2 NKC-D for the type F prototype, and 14 NKC-U, 2 NKC-D and $3 \mathrm{KSCC}$ for the type f variant.

Sequence analysis of EBNA-2 DNA and BamHI F and $f$ variants. The DNA sequences of EBNA-2A and -2B subtypes and the BamHI F prototype and $\mathrm{f}$ variant were confirmed by direct sequencing of the PCR products from representative NPC cases with each subtype/variant [case no. 1 (Fukuoka), no. 2 (Fukuoka), no. 56 (Guilin) and no. 46 (Guilin) for EBNA-2A, EBNA-2B, F and f, respectively] (data not shown).

\section{Discussion}

In this study, we found similarities as well as differences between Guilin, China and Fukuoka, Japan with reference to EBV infection and NPC. In both China and Japan, the EBERpositive rate was significantly higher in NPC tissues than nonneoplastic nasopharyngeal tissues (95 vs. $46 \%$ in Guilin and 55 vs. $32 \%$ in Fukuoka), suggesting the oncogenic contribution of EBV in NPC in the two localities. However, there were also differences between the two populations: 1) The EBERpositive rate among NPC was much higher in Guilin than Fukuoka (95 vs. 55\%), although it was not different in nonneoplastic tissue (46 vs. 32\%). 2) NPC developed in younger generations in Guilin compared with NPC patients in Fukuoka (mean age: 45.5 vs. 66.5). 3) The histological composition of NPC was quite different: NKC-U was predominant in Guilin (84\%), while as much KSCC as NKC-U was found in Fukuoka (38 and $42 \%$, respectively). EBER positivity was higher in NKC-U than KSCC in the two populations. In Fukuoka, there were more EBV non-associated KSCC cases compared with China. These findings suggest possible differences in NPC- 
Table V. Summary of clinicopathological features, results of EBER in situ hybridization and EBV genetic subtypes in Guilin, Chinese NPC cases.

\begin{tabular}{|c|c|c|c|c|c|c|}
\hline Case & Age (years) & Gender & Histology & EBER & EBNA-2 subtype & BamHI F/f \\
\hline 13 & 34 & Male & NKC-U & + & A & ND \\
\hline 14 & 44 & Female & NKC-U & + & $\mathrm{A}$ & $\mathrm{F}$ \\
\hline 15 & 63 & Female & NKC-U & + & A & ND \\
\hline 16 & 63 & Male & NKC-U & + & $\mathrm{A}$ & $f$ \\
\hline 17 & 37 & Male & NKC-D & + & $\mathrm{A}$ & $f$ \\
\hline 18 & 38 & Female & KSCC & + & A & ND \\
\hline 19 & 55 & Male & NKC-U & + & $\mathrm{A}$ & $f$ \\
\hline 20 & 50 & Male & NKC-U & + & A & ND \\
\hline 21 & 68 & Male & NKC-U & + & A & ND \\
\hline 22 & 57 & Female & NKC-U & + & A & ND \\
\hline 23 & 45 & Female & NKC-U & + & $\mathrm{A}$ & ND \\
\hline 24 & 48 & Male & NKC-U & + & A & ND \\
\hline 25 & 47 & Female & NKC-U & + & A & ND \\
\hline 26 & 40 & Male & NKC-D & + & $\mathrm{A}$ & ND \\
\hline 27 & 41 & Male & NKC-U & + & A & $f$ \\
\hline 28 & 36 & Male & NKC-U & + & A & ND \\
\hline 29 & 26 & Male & NKC-U & + & A & ND \\
\hline 30 & 39 & Male & NKC-U & + & A & ND \\
\hline 31 & 36 & Male & NKC-U & + & A & ND \\
\hline 32 & 36 & Female & NKC-U & + & A & ND \\
\hline 33 & 56 & Male & NKC-U & + & A & $f$ \\
\hline 34 & 41 & Female & NKC-D & + & A & ND \\
\hline 35 & 40 & Male & NKC-U & + & $\mathrm{A}, \mathrm{B}$ & $\mathrm{f}$ \\
\hline 36 & 56 & Male & NKC-U & + & A & $\mathrm{f}$ \\
\hline 37 & 53 & Male & NKC-U & + & B & ND \\
\hline 38 & 44 & Male & NKC-U & + & A & $\mathrm{f}$ \\
\hline 39 & 50 & Male & NKC-U & + & A, B & ND \\
\hline 40 & 38 & Male & KSCC & + & A, B & $\mathrm{f}$ \\
\hline 41 & 42 & Male & NKC-D & + & A, B & f \\
\hline 42 & 78 & Female & NKC-U & + & A, B & $\mathrm{F}$ \\
\hline 43 & 42 & Male & NKC-U & + & $\mathrm{A}$ & $\mathrm{F}$ \\
\hline 44 & 61 & Male & NKC-U & + & A & $\mathrm{F}$ \\
\hline 45 & 52 & Male & NKC-U & + & A, B & ND \\
\hline 46 & 31 & Male & NKC-U & + & A & $\mathrm{f}$ \\
\hline 47 & 53 & Male & NKC-U & + & $\mathrm{A}$ & $\mathrm{f}$ \\
\hline 48 & 40 & Male & NKC-U & + & A & ND \\
\hline 49 & 40 & Male & KSCC & + & A & $\mathrm{f}$ \\
\hline 50 & 53 & Male & NKC-D & + & A & $\mathrm{F}$ \\
\hline 51 & 72 & Male & NKC-D & + & A & ND \\
\hline 52 & 43 & Male & NKC-U & + & A & $\mathrm{f}$ \\
\hline 53 & 30 & Male & NKC-U & + & A & $f$ \\
\hline 54 & 41 & Male & NKC-U & + & A, B & $f$ \\
\hline 55 & 34 & Male & KSCC & + & $\mathrm{A}$ & $\mathrm{f}$ \\
\hline 56 & 56 & Male & NKC-D & + & A & $\mathrm{F}$ \\
\hline 57 & 33 & Male & NKC-U & + & A & $\mathrm{f}$ \\
\hline
\end{tabular}

KSCC, keratinizing squamous cell carcinoma; NKC, non-keratinizing carcinoma; -D, differentiated subtype; -U, undifferentiated subtype and $\mathrm{ND}$, not detected. 
associated EBV genetics or in co-factors involved in NPC tumorigenesis between Guilin, China and Fukuoka, Japan. NPC develops in a shorter period after EBV infection in China versus Japan since most children in China and Japan are seroconverted against EBV within 1 year of age (28). This finding also supports the above conclusion.

Despite the limited number of geographically-oriented studies concerning viral genomics in patients with NPC, the specific EBV genotypes are believed to be determined geographically (29). Studies indicate that EBV type A is highly predominant in Japanese NPC in the general Japanese population, but that type B variant is quite rare $(15,30,31)$. Similarly, a Chinese study that involved the genotyping of EBV carried out in 25 NPC cases from Guangdong, Southern China, demonstrated a predominance of the type A virus with only one case of the type B virus being found (18). In this regard, a study in Taiwan showed that $84 \%$ of NPC were infected with type A virus, while $\sim 17 \%$ were twice as infected with type A and B viruses (32). Furthermore, the genotype of EBV could be different based on the disease and organ involved, since a higher incidence of type B EBV has been reported in Japanese nasal T-cell lymphoma patients (33). As with other studies in Japan and China mentioned above, our study showed that most Guilin (37/45) and Fukuoka (11/12) cases were infected with type A virus, whereas type B DNA was identified only in one case in each group. Moreover, seven (7/45) cases from Guilin showed dual infection by EBV type $\mathrm{A}$ and B viruses. In this context, Sixbey et al (12) were the first group to report EBV coinfection in immunocompetent hosts by demonstrating the two types of EBV by PCR in throat washings from $9 \%$ of healthy viral carriers. Thus, coinfection occurs in immunocompetent and immunocompromised patients $(32,34-36)$. Due to EBV polymorphisms, the specific immune response induced after the primary infection does not confer absolute protection against other existing EBV genotypes and thus distinct genotypes can sequentially infect different cell types in an individual (27).

EBV has various genetic polymorphisms due to repetitive sequence and allelic sequence divergences, resulting in extensive RFLP $(23,31)$. Bam HI F and $\mathrm{f}$ variants are based on this RFLP. Several lines of evidence indicate the strong biased association of the $f$ variant with NPC in Southern China. In Hong Kong, the high frequency of the f variant in NPC (24/28, $86 \%$ ) and its rarity in peripheral T-cell lymphoma and lymphoblastoid cell lines were demonstrated $(20,32)$. In Southern China, the $\mathrm{f}$ variant was shown at a much higher frequency not only in overt NPC patients but also in individuals at a high risk for developing NPC versus healthy individuals (23). Moreover, it was reported that at five years after radiotherapy, the majority of people in remission for NPC no longer harbored the f variant in their oropharynx (23), suggesting a conversion or replacement of the f genotype by the prototype $F$ virus. However, the frequency of the $f$ variant in the peripheral circulation of healthy individuals was reported to be low (18.9\%) after PCR analysis of throat washings (23). These findings suggest a close association of the $f$ variant with NPC oncogenesis and differential tumorigenesis of different EBV strains. Unlike Asia, the f variant was not present in NPC tissues from North Africa (29), an area intermediate for NPC occurrence, indicating that the $f$ polymorphism is not an indispensable prerequisite for NPC development. Thus, it may be that a geographical and genetic association with the EBV genotypes has a key role in the development of different types of EBV-associated malignancies. The $\mathrm{f}$ variant was reported to be predominant in NPC patients from South China, Taiwan and Hong Kong $(19,20,22,32)$, while genotype F prevails in the USA and Africa $(30,37)$. The $\mathrm{F}$ and $\mathrm{f}$ genotypes are found in Europe and Malaysia $(27,29,30,38)$. Few studies exist on the genotypes in Japan. The predominance of the F prototype in NPC was shown in patients from Wakayama, a Midwest city of Japan (31). In patients with oral SCC, type A EBV with the F genotype was dominant in Kitakyushu and Kumamoto, cities located in the western area of Japan, while type B EBV with the F genotype was mostly found in Okinawa, the southernmost city of Japan (38). In our study, all successfully analyzed cases from Fukuoka, a city in the western part of Japan, demonstrated the prototype F, while those from Guilin, located in Southern China, showed the predominance of the $f$ variant over the F prototype (79 vs. $21 \%$ ), a rate lower than that of the $f$ variant as reported by Lung et al $(20,23)$. The different distribution of the $\mathrm{f}$ variant in NPC may explain the different tumorigenesis. This may be one of the reasons why the incidence of NPC was lower compared with different rates of histological types and the older onset age of patients from Fukuoka, Japan, compared with Guilin, China. The geographical distribution of specific EBV genotypes may result from the link between the genetic disposition of the human population and specific EBV genotypes.

In conclusion, the findings of this study add support to the notion that Chinese and Japanese NPC may be distinct in its development. The genetic structure and biological functions of the EBV strain associated with endemic NPC in Guilin may be different compared with that associated with NPC in Fukuoka, and probably explains the differences in the histologal and patient profiles.

\section{Acknowledgements}

The authors would like to thank Mr. Y. Kamihara, Department of Pathology, Fukuoka University Hospital, Ms. C. Fujita and Ms. M. Ishiguro, Department of Pathology, Fukuoka University School of Medicine, for their skillful help in in situ hybridization, PCR and cutting sections, respectively.

\section{References}

1. Spano JP, Busson P, Atlan D, Bourhis J, Pignon JP, Esteban C and Armand JP: Nasopharyngeal carcinomas: an update. Eur J Cancer 39: 2121-2135, 2003.

2. zur Hausen H, Schulte-Holthausen H, Klein G, Henle W, Henle G, Clifford P and Santesson L: EBV DNA in biopsies of Burkitt tumours and anaplastic carcinomas of the nasopharynx. Nature 228: 1056-1058, 1970.

3. Pallesen G, Hamilton-Dutoit SJ, Rowe M and Young LS: Expression of Epstein-Barr virus latent gene products in tumour cells of Hodgkin's disease. Lancet 337: 320-322, 1991.

4. Jeon YK, Lee BY, Kim JE, Lee SS and Kim CW: Molecular characterization of Epstein-Barr virus and oncoprotein expression in nasopharyngeal carcinoma in Korea. Head Neck 26: 573-583, 2004

5. Borisch B, Hennig I, Laeng RH, Waelti ER, Kraft R and Laissue J: Association of the subtype 2 of the Epstein-Barr virus with T-cell non-Hodgkin's lymphoma of the midline granuloma type. Blood 82: 858-864, 1993. 
6. Borisch B, Caioni M, Hurwitz N, Dommann-Scherrer C, Odermatt B, Waelti E, Laeng RH, Kraft R and Laissue J: Epstein-Barr virus subtype distribution in angioimmunoblastic lymphadenopathy. Int J Cancer 55: 748-752, 1993.

7. Uhara H, Sato Y, Mukai K, Akao I, Matsuno Y, Furuya S, Hoshikawa T, Shimosato Y and Saida T: Detection of EpsteinBarr virus DNA in Reed-Sternberg cells of Hodgkin's disease using the polymerase chain reaction and in situ hybridization. Jpn J Cancer Res 81: 272-278, 1990.

8. Peh SC, Kim LH and Poppema S: Frequent presence of subtype A virus in Epstein-Barr virus-associated malignancies. Pathology 34: 446-450, 2002

9. Howe JG and Steitz JA: Localization of Epstein-Barr virusencoded small RNAs by in situ hybridization. Proc Natl Acad Sci USA 83: 9006-9010, 1986.

10. Dambaugh T, Hennessy K, Chamnankit L and Kieff E: U2 region of Epstein-Barr virus DNA may encode Epstein-Barr nuclear antigen 2. Proc Natl Acad Sci USA 81: 7632-7636, 1984.

11. Young LS, Yao QY, Rooney CM, Sculley TB, Moss DJ, Rupani H, Laux G, Bornkamm GW and Rickinson AB: New type B isolates of Epstein-Barr virus from Burkitt's lymphoma and from normal individuals in endemic areas. J Gen Virol 68: 2853-2862, 1987

12. Sixbey JW, Shirley P, Chesney PJ, Buntin DM and Resnick L: Detection of a second widespread strain of Epstein-Barr virus. Lancet 2: 761-765, 1989.

13. Rickinson AB, Young LS and Rowe M: Influence of the Epstein-Barr virus nuclear antigen EBNA 2 on the growth phenotype of virus-transformed B cells. J Virol 61: 1310-1317, 1987.

14. Sample J, Young L, Martin B, Chatman T, Kieff E and Rickinson A: Epstein-Barr virus types 1 and 2 differ in their EBNA-3A, EBNA-3B, and EBNA-3C genes. J Virol 64: 4084-4092, 1990.

15. Kunimoto M, Tamura S, Tabata T and Yoshie O: One-step typing of Epstein-Barr virus by polymerase chain reaction: predominance of type 1 virus in Japan. J Gen Virol 73: 455-461, 1992.

16. Buck M, Cross S, Krauer K, Kienzle N and Sculley TB: A-type and B-type Epstein-Barr virus differ in their ability to spontaneously enter the lytic cycle. J Gen Virol 80: 441-445, 1999.

17. Zimber U, Adldinger HK, Lenoir GM, Vuillaume M, Knebel-Doeberitz MV, Laux G, Desgranges C, Wittmann P, Freese UK, Schneider U, et al: Geographical prevalence of two types of Epstein-Barr virus. Virology 154: 56-66, 1986.

18. Chen XY, Pepper SD and Arrand JR: Prevalence of the A and B types of Epstein-Barr virus DNA in nasopharyngeal carcinoma biopsies from southern China. J Gen Virol 73: 463-466, 1992.

19. Lung ML and Chang GC: Detection of distinct Epstein-Barr virus genotypes in NPC biopsies from southern Chinese and Caucasians. Int J Cancer 52: 34-37, 1992.

20. Lung ML, Chang RS, Huang ML, Guo HY, Choy D, Sham J, Tsao SY, Cheng P and Ng MH: Epstein-Barr virus genotypes associated with nasopharyngeal carcinoma in southern China. Virology 177: 44-53, 1990.

21. Klemenc P, Marin J, Soba E, Gale N, Koren S and Strojan P: Distribution of Epstein-Barr virus genotypes in throat washings, sera, peripheral blood lymphocytes and in EBV positive tumor biopsies from Slovenian patients with nasopharyngeal carcinoma. J Med Virol 78: 1083-1090, 2006.

22. Lung ML, Chang GC, Miller TR, Wara WM and Phillips TL: Genotypic analysis of Epstein-Barr virus isolates associated with nasopharyngeal carcinoma in Chinese immigrants to the United States. Int J Cancer 59: 743-746, 1994.
23. Lung ML, Lam WP, Sham J, Choy D, Yong-Sheng Z, Guo HY and $\mathrm{Ng} \mathrm{MH}$ : Detection and prevalence of the 'f ' variant of Epstein-Barr virus in southern China. Virology 185: 67-71, 1991.

24. Lung ML, Sham JS, Lam WP and Choy DT: Analysis of Epstein-Barr virus in localized nasopharyngeal carcinoma tumors. Cancer 71: 1190-1192, 1993.

25. Chan JKC, Bray F, McCarron P, Foo W, Lee AWM, Yip T, Kuo TT, Pilch BZ, Wenig BM, Huang D, Lo KW, Zeng YX and Jia WH: Nasopharyngeal Carcinoma. IARC Press, Lyon, 2005.

26. Borisch B, Finke J, Hennig I, Delacretaz F, Schneider J, Heitz PU and Laissue JA: Distribution and localization of Epstein-Barr virus subtypes $A$ and $B$ in AIDS-related lymphomas and lymphatic tissue of HIV-positive patients. J Pathol 168: 229-236, 1992

27. Henry S, Sacaze C, Berrajah L, Karray H, Drira M, Hammami A, Icart $\mathbf{J}$ and Mariame B: In nasopharyngeal carcinoma-bearing patients, tumors and lymphocytes are infected by different Epstein-Barr virus strains. Int J Cancer 91: 698-704, 2001.

28. Kure S, Kikuchi Y and Yoshie O: Enzyme-linked immunosorbent assay for detection of antibodies to Epstein-Barr virusassociated nuclear antigen-1 using a synthetic oligopeptide. Microbiol Immunol 30: 831-836, 1986.

29. Bouzid M, Djennaoui D, Dubreuil J, Bouguermouh A, Ellouz D, Abdelwahab J, Decaussin G and Ooka T: Epstein-Barr virus genotypes in NPC biopsies from north Africa. Int J Cancer 56: 468-473, 1994.

30. Khanim F, Yao QY, Niedobitek G, Sihota S, Rickinson AB and Young LS: Analysis of Epstein-Barr virus gene polymorphisms in normal donors and in virus-associated tumors from different geographic locations. Blood 88: 3491-3501, 1996.

31. Tamura S, Kunimoto M, Tabata T and Yoshie O: Genotypic analysis of Epstein-Barr virus associated with nasopharyngeal carcinoma of Japanese patients. Jpn J Cancer Res 84: 246-249, 1993.

32. Wu SJ, Lay JD, Chen CL, Chen JY, Liu MY and Su IJ: Genomic analysis of Epstein-Barr virus in nasal and peripheral T-cell lymphoma: a comparison with nasopharyngeal carcinoma in an endemic area. J Med Virol 50: 314-321, 1996.

33. Miyashita T, Kawaguchi H, Asada M, Mizutani S and Ibuka T: Epstein-Barr virus type B in patient with T-cell lymphoma. Lancet 337: 1045-1046, 1991.

34. Yao QY, Tierney RJ, Croom-Carter D, Cooper GM, Ellis CJ, Rowe $\mathrm{M}$ and Rickinson $\mathrm{AB}$ : Isolation of intertypic recombinants of Epstein-Barr virus from T-cell-immunocompromised individuals. J Virol 70: 4895-4903, 1996.

35. Srivastava G, Wong KY, Chiang AK, Lam KY and Tao Q: Coinfection of multiple strains of Epstein-Barr virus in immunocompetent normal individuals: reassessment of the viral carrier state. Blood 95: 2443-2445, 2000.

36. Correa RM, Fellner MD, Alonio LV, Durand K, Teyssie AR and Picconi MA: Epstein-barr virus (EBV) in healthy carriers: Distribution of genotypes and $30 \mathrm{bp}$ deletion in latent membrane protein-1 (LMP-1) oncogene. J Med Virol 73: 583-588, 2004.

37. Sidagis J, Ueno K, Tokunaga M, Ohyama M and Eizuru Y: Molecular epidemiology of Epstein-Barr virus (EBV) in EBVrelated malignancies. Int J Cancer 72: 72-76, 1997.

38. Higa M, Kinjo T, Kamiyama K, Iwamasa T, Hamada $T$ and Iyama K: Epstein-Barr virus (EBV) subtype in EBV related oral squamous cell carcinoma in Okinawa, a subtropical island in southern Japan, compared with Kitakyushu and Kumamoto in mainland Japan. J Clin Pathol 55: 414-423, 2002. 